\title{
Handel in kleurstoffen op de Antwerpse markt tijdens de XVe eeuw *
}

\author{
G. ASAERT
}

De lakenververij, een van de zogenaamde veredelingstechnieken van de oude draperie, was een ingewikkelde en dure onderneming. De verver moest niet alleen een gedegen vakmanschap bezitten en een grote lichaamskracht kunnen opbrengen maar de outillage van een ververij vergde bovendien een niet geringe investering ${ }^{1}$.

De kleurstoffen die de middeleeuwse ververs in hun kuipen gebruikten waren van organische oorsprong. Pas in de negentiende eeuw ging men over óp synthetische kleurmiddelen. In de oude Nederlanden bedienden de lakenververs zich bijna uitsluitend van kleurstoffen die van verfplanten werden verkregen. Elke plantensoort kon slechts één hoofdkleur opleveren zodat men van diverse plantenvariëteiten moest gebruik maken. In de loop van de tijd deed zich een evolutie in de toepassing voor. Toen in de zestiende eeuw nieuwe verfplanten in de pas ontsloten gebieden van de Nieuwe Wereld werden aangetroffen gingen deze van langsom meer de van ouds gekende soorten verdringen. Zo bleek indigo een veel krachtiger en gelijkmatiger te verdelen kleurstof te zijn dan de traditionele blauwe verfstof wede die samen met de roodkleurende meekrap de twee meest gebruikte middeleeuwse kleurstoffen waren ${ }^{2}$.

Van deze was wede ${ }^{3}$ beslist de belangrijkste. De wedeplant is een tweejarig kruis-

* Onderhavige tekst is de uitgewerkte en van kritisch apparaat en tabellen voorziene versie van een lezing gehouden op het Colloquium Economische Geschiedenis van België. Behandeling van de bronnen en problematiek (Brussel, 17-19 november 1971).

Gebruikte afkortingen:

Adr.: Adriaen; Aern.: Aernoud; al.: alias; Andr.: Andries; CL: Claus; Corn.: Cornelis; f.: filius; Giel.: Gielis; Godt.: Godevaert; H.: Henric; Hm.: Herman; J.: Jan; Jac: Jacob; Katl.: Katline; Laur.: Laureis; lb. gro. Br.: ponden groten Brabants; lb. gro. VI.: ponden groten Vlaams; Math.: Mathijs; ML: Michiel; P.: Peter; SAA: Stadsarchief Antwerpen; SR: Schepenregister; W.: Willem; wed.: weduwe; Wr.: Wouter.

1. E. Carus-Wilson, 'The Woollen Industry', The Cambridge Economie History of Europe, II, Trade and Industry in the Middle Ages (Cambridge, 1952) 379.

2. Ibidem, 127.

3. Latijn: isatis tinctoria, glastum, vitrum; Frans: guède, waide, pastel; Duits: Waid, Weidt; Engels: woad, wedde; Italiaans: guado, gualo. Cf. G. de Poerck, "Wazaru' et autres noms médiévaux de la guède', Archivum Latinitatis Medii Aevi (Bulletin du Cange), XVI (1943) 165-178. Enkele belangrijke studies: F. Borlandi, 'Note per la storia delle produzione e del commercio di una materia prima. Il guado nel medio evo', Studi in onori di G. Luzzato, I (Milaan, 1950) 297-324; J. B. Hurry, The Woad-Plant and its Dye (Londen, 1930); E. E. Ploss, Ein Buch von alten Farben. Technologie der Textilfarben im Mittelalter, mit einem Ausblick auf die festen Farben (Heidelberg-

BMGN88afl.3. 


\section{G. ASAERT}

bloemig gewas dat in de lente wordt gezaaid en pas het volgende jaar tot ontwikkeling komt. Wanneer de bladeren dik en vettig zijn worden ze geoogst, tot vier a vijf keer per jaar, en wel van het voorjaar tot september ${ }^{4}$. Zij werden gemalen in de zogenaamde wedemolen waarvan wij geen sporen in de Antwerpse documenten hebben teruggevonden ${ }^{5}$. De aldus geplette bladeren werden in de rivier gewassen, in de zon gedroogd en vervolgens in hopen gelegd en zo tot gisting gebracht. $\mathrm{Na}$ drogen, stampen en zeven werd het eindprodukt aan de ververs verkocht ${ }^{6}$.

De voornaamste Europese teeltgebieden bevonden zich in Thuringen ${ }^{7}$ en in het land van Gulik, in de streek van Toulouse ${ }^{8}$, Albi en Montauban, ook in Normandië en in Picardië 9 . In Italië waren het vooral Piemont, Udine en niet te vergeten Toscane, terwijl in de Lage Landen in het bijzonder de leemstreek van de Zuidelijke Nederlanden kan worden vermeld ${ }^{10}$.

Mede of meekrap ${ }^{11}$ is een overblijvend gewas dat na twee of drie jaar wordt geoogst. Hier zijn het niet de bladeren maar wel de wortelstokken, soms tot één meter lang, die als grondstof voor de rode kleur bruikbaar zijn ${ }^{12}$. Als men de kern

Berlijn, 1962); R. Scholz, Aus der Geschichte des Farbstoffhandels im Mittelalter (München, 1929). Voor studies betreffende gewestelijke wedecultuur verwijzen wij naar de volgende voetnoten.

4. P. Lindemans, Geschiedenis van de landbouw in België, II (Antwerpen, 1952 )257-258; B. H. Slicher van Bath, De agrarische geschiedenis van West-Europa (500-1850) (Utrecht-Antwerpen, 1960) 279, 297.

5. Tot dezelfde conclusie is reeds gekomen R. van Passen, 'Het toponiem weemoes', Mededelingen van de Vereniging voor Naamkunde te Leuven en de Commissie voor Naamkunde te Amsterdam, XXXIX (1963) 176.

6. W. L. J. de Nie, De ontwikkeling der Noordnederlandsche textielververij van de veertiende tot de achttiende eeuw (Leiden, 1937) 63-68.

7. A. Rach, 'Die zweite Blütezeit des Erfurter Waidhandels', Jahrbücher für National-ökonomie und Statistik, CLXXI (1959) 24-88; W. Schnellenkamp, Beiträge zur Entstehungsgeschichte der Thüringer Waidstädte und ihrer Nachbarstädte, I (Erfurt-Jena, 1929); E. Wagner, 'Waidbau und Waidhandel in Thüringen. Ein wirtschaftsgeschichtlicher Überblick', Bauernspiegel (1935) vi-vii; D. G. Schreber, Beschreibung des Waidtes, dessen Baues, Bereitung und Gebrauchs zum Farben ... besonders in Thüringen (Halle, 1752); K. Mohring, 'Der Waidbau, das 'goldene Vlies' Thüringens', Thüringer Volkskalender (1952) 45-50.

8. Ph. Wolff, Commerces et marchands de Toulouse (vers 1350-vers 1450) (Parijs, 1954); G. Caster, Le commerce du pastel et de l'épicerie d Toulouse (1450-1561) (Toulouse, 1962); idem, 'Types économiques et sociaux du XVIe siècle. Le pastelier toulousain', Annales. Economies. Sociétés. Civilisations, IX (1954) 63-74.

9. E. Carus-Wilson, 'La guède française en Angleterre: un grand commerce du moyen âge', Revue du Nord, XXXV (1953) 89-106.

10. L. van Acker, 'Teelt van wede (pastel) in West-Vlaanderen', Biekorf, LXII (1961) 87; L. Génicot, 'La guède namuroise', Belgisch tijdschrift voor filologie en geschiedenis, XL (1962) 685687; J. Herbillon en A. Joris, 'Les moulins à guède en Hesbaye au moyen âge', ibidem, XLII (1964) 495-515; A. Joris, 'La guède en Hesbaye au moyen âge (XIIIe-XVe siècle)', Le Moyen Age, LXIX (1963) 773-789; idem, 'Les moulins à guède dans le comté de Namur pendant la seconde moitié du XIIIe siècle', ibidem, LXV (1959) 253-278.

11. Latijn: rubia tinctorum; Frans: garance; Duits: Krapp; Engels: madder.

12. Enkele belangrijke studies: J. de Kanter, De teling en bereiding der meekrap (Dordrecht, 
van de wortel of het vlezige deel rond die kern gebruikt spreekt men van meekrap of van mede ${ }^{13}$. De meekrapplant wordt niet gezaaid maar gepoot in mei, in goed gedolven en gemeste grond. In de middeleeuwen was het in de Nederlanden op de zware gronden langs de zeekust, voornamelijk in Vlaanderen en Zeeland, het belangrijkste handelsgewas ${ }^{14}$. Laatstgenoemd gewest is eeuwenlang in Europa de monopoliehouder geweest tot Franse meekrap in de negentiende eeuw een ernstige concurrent werd. Door de uitvinding van synthetische kleurstoffen tegen het einde van het derde kwart van de negentiende eeuw ging de medecultuur definitief ten onder.

Omdat de teelt- en de consumptiegebieden, vooral wat wede betreft, ver van elkaar verwijderd lagen - een uitzondering is Toscane met Florence - kan kleurstof als handelswaar heel wat stof tot studie bieden. Bovendien voelt niet alleen de geïnteresseerde in economische geschiedenis zich door dit onderwerp aangetrokken. Het is eveneens onderzoekingsterrein voor de landbouwhistoricus en voor de lokaalhistoricus, ja zelfs filologen hebben, zoals reeds is gebleken, voor dit onderwerp belangstelling kunnen opbrengen.

In de Antwerpse historiografie werd dit onderwerp nog niet rechtstreeks aangesneden. Wel verneemt men terloops een en ander bij F. Prims ${ }^{15}$, O. Desmedt ${ }^{16}$, J. Craeybeckx ${ }^{17}$ en E. Coornaert ${ }^{18}$. Antwerpen kende reeds sedert het begin van de dertiende eeuw en mogelijk ook vroeger ${ }^{19}$, een bloeiende lakenproduktie, die voor de stad eigenlijk nooit zo van vitaal belang is geweest als voor de meeste steden van het graafschap Vlaanderen. In tegenstelling tot elders heeft men daar de steeds groeiende hoeveelheden Engels laken die de Nederlanden binnenstroomden niet

1802); B. W. van der Kloot Meyburg, 'Bijdrage tot de geschiedenis van de meekrapcultuur in Nederland', Economisch-historisch jaarboek, XVIII (1934) 59-153; J. M. G. van der Poel, 'De teelt van meekrap', Ceres en Clio. Zeven variaties op het thema landbouw/geschiedenis (Wageningen, 1964) 129-165; C. Wiskerke, 'De geschiedenis van het meekrapbedrijf in Nederland', Economischhistorisch jaarboek, XXV (1952) 1-144.

13. N. W. Posthumus, De geschiedenis van de Leidsche lakenindustrie, I ('s-Gravenhage, 1908) 53 , nr. 4.

14. Lindemans, Geschiedenis van de landbouw, II, 255; J. Mertens, De laatmiddeleeuwse landbouweconomie in enkele gemeenten van het Brugse platteland (Brussel, 1970) 82-83.

15. F. Prims, Geschiedenis van het Antwerpse turfdragersambacht, 1447-1863 (Antwerpen, 1923) 81-82; idem, 'De statuten van de Antwerpsche lakengilden in het begin der zestiende eeuw', Verslagen en mededeelingen van de Koninklijke Vlaamsche Academie voor Taal-en Letterkunde (Ledeberg-Gent, 1939) 19-45; idem, 'Het lakenverwersambacht', Antverpiensia, 20e reeks, XI (Antwerpen, 1950) 67-68.

16. O. Desmedt, De Engelse natie te Antwerpen in de 16e eeuw (1496-1582), II (Antwerpen, 1954) 399-400.

17. J. Craeybeckx, Un grand commerce d'importation: les vins de France aux anciens Pays-Bas (XIIIe-XVIe siècle), Ports, Routes, Trafics, IX (Parijs, 1958) 144-145.

18. E. Coornaert, Les Francais et le commerce international à Anvers (fin XVe et XVIe siècles), II (Parijs, 1961) 104, noot 4-5, 160.

19. Cf. A. L. J. van de Walle, 'De archeologische opgravingen in het oud stadscentrum te Antwerpen', Antwerpen. Tijdschrift der stad, VI (1960) ii, 48-61. 


\section{G. ASAERT}

als een bedreiging aangezien. De stadsmagistraat heeft het niet noodzakelijk geacht dit laken als een gevaar voor de eigen industrie te weren. Veeleer is het tegendeel waar. Omdat de Engelse wijze van lakenbereiding op het vasteland minder op prijs werd gesteld is men te Antwerpen de appretuur resoluut gaan bevorderen en groeide de stad in de loop van de vijftiende eeuw meer en meer uit tot een belangrijk centrum van lakenbereiding ${ }^{20}$. Het is duidelijk dat naast de bereiders ook de ververs uit deze evolutie voordeel haalden. Hun bedrijvigheid hing echter af van de bevoorrading in kleurstoffen. $\mathrm{Nu}$ is bekend dat sedert de laatste decenniën van de vijftiende eeuw de Antwerpse markt als het ware overspoeld werd door pastel uit de streek van Toulouse. Vooral de zestiende eeuw, Antwerpens Gouden Eeuw, werd door een belangrijke wede-import gekenmerkt. Lodovico Guicciardini, een Florentijn die jarenlang te Antwerpen verbleef en als een tamelijk betrouwbare bron mag worden aangezien, verhaalt dat de haven jaarlijks 40.000 balen pastel importeerde ${ }^{21}$. Aangezien echter vóór 1480 de Toulouser wede de Nederlanden nog niet bereikte ${ }^{22}$ rijst de vraag uit welke produktiegebieden de Scheldestad zijn kleurstoffen betrok tijdens het grootste deel van de vijftiende eeuw.

Naar Prims mededeelt kwam wede uit Gulik en Erfurt, ook wel uit Frankrijk en Portugal $^{23}$. Coornaert neemt deze zienswijze over. Antwerpen ontving 'un peu de 'waid' de Juliers et d'Erfurt, même de Breslau. ${ }^{24}$. Op het eind van de vijftiende eeuw verdrong de Toulouser pastel de import van wede uit Normandië en Picardië ${ }^{25}$.

Picardië was inderdaad een van de belangrijkste teeltgebieden in de middeleeuwen. De roem van Amiens was op 'waide' gebouwd en Engeland was de belangrijkste afnemer $^{26}$. In de vijftiende eeuw behoorde de grote tijd van de Picardische wedeexport naar Engeland tot het verleden. Kooplieden van Amiens gingen nog slechts hun waar aan Engelse opkopers aanbieden te Kales en op de Brabantse jaarmark$\operatorname{ten}^{27}$. Het zou dus geenszins onlogisch zijn Noord-Franse wede op de Antwerpse markt aan te treffen.

20. Desmedt, Engelse natie, I, 83-84.

21. Descrittione di M. Lodovico Guicciardini patritio Fiorentino, di tutti i Paesi Bassi, altrimente detti Germania inferiore (Antwerpen: W. Silvius, 1567) 125. Dit cijfer lijkt geenszins overdreven. Cf. W. Brulez, 'De handelsbalans der Nederlanden in het midden van de 16e eeuw', Bijdragen voor de Geschiedenis der Nederlanden, XXI (1967) 284-285.

22. Z. W. Sneller en W. S. Unger, Bronnen tot de geschiedenis van den handel met Frankrijk, 7531585,1, RGP, Grote Serie LXX ('s-Gravenhage, 1930) 179. Vier poorters van Leiden geven op 18 december 1481, voor het gerecht van Bergen-op-Zoom, een verklaring betreffende twee partijen weed van Toulouse, die zij van Gomes de Souria, koopman uit Spanje, te Middelburg hebben gekocht.

23. Prims, Turf dragersambacht, 88; idem, 'De statuten', 17.

24. Coornaert, Les Français, II, 104, noot 4.

25. Ibidem, I, 324.

26. Carus-Wilson, 'The Woollen Industry', 377.

27. M. R. Thielemans, Bourgogne et Angleterre. Relations politiques et économiques entre les Pays-Bas Bourguignons et l'Angleterre 1435-1467 (Brussel, 1966) 235. 
Wel kwam het ons vrij zonderling voor dat de Rijnlandse inbreng door Coornaert zo laag werd geschat. Tussen Aken en Keulen, dat is niet zo heel ver van Antwerpen, bevond zich immers een uitgestrekt wedegebied. Gelet op de groeiende handelsbetrekkingen met Keulen behoort een grotere afname van Rijnlandse kleurstof tot de mogelijkheden. Een onderzoek was het ondernemen waard.

Meekrap werd volgens Prims ${ }^{28}$ betrokken uit Zeeland en de eigen polderstreek, wat zeer aanvaardbaar voorkomt. Een tweede vraag die men zich mag stellen: werd alle te Antwerpen geïmporteerde kleurstof in de plaatselijke nijverheid verbruikt of fungeerde deze Scheldehaven als een distributiecentrum dat ook andere draperiesteden heeft bevoorraad?

Om deze en andere vragen te kunnen beantwoorden werd te rade gegaan bij het Antwerpse schepenenprotocol van de vijftiende eeuw ${ }^{29}$ dat vrij gaaf tot ons is gekomen en voor de geschiedenis van Antwerpens late middeleeuwen zowat het enige materiaal van grotere omvang is, bruikbaar voor de geschiedenis van het economisch leven in de Scheldestad en erbuiten. In deze protocollen van vrijwillige rechtspraak, of schepenbrieven, zoals ze enigszins ten onrechte gewoonlijk worden genoemd, vindt men de huishouding van de burgerij in een zeer groot aantal akten weerspiegeld. Wanneer men zich realiseert dat wat Antwerpen betreft, alleen al voor de vijftiende eeuw (tot 1480), een 300.000 minuten van akten bewaard zijn gebleven, groeit een gevoel van onmacht ten opzichte van de enorme en indrukwekkende hoeveelheid materiaal die nog op bewerking wacht. Dit bronnenmateriaal kan natuurlijk bezwaarlijk als statistisch worden gecatalogeerd. Toch biedt het, mits de nodige omzichtigheid in acht wordt genomen, nog een redelijke kwantitatieve bruikbaarheid. Dank zij een, naar wij aannemen uitputtend, onderzoek van de 96 schepenregisters van de periode 1394-1480 konden een driehonderdtal contracten betreffende verkoop van verfstoffen worden opgespoord. Omdat deze akten diverse bruikbare elementen bevatten is hun aantal groot genoeg om geldige conclusies te trekken. Er is vooreerst de datum van elke acte waardoor de spreiding in de tijd kan worden bestudeerd; er zijn de namen van de contracterende partijen met opgave van beroep en herkomst van deze mensen, wat ons voor de koper het milieu leert kennen waarin de produkten terecht komen en voor de verkoper de streek waaruit de kleurstof wordt ingevoerd. Verder wordt de kwantiteit van de verhandelde waar of de prijs van de gehele partij opgegeven. Wanneer beide elementen in eenzelfde contract worden aangetroffen kan de prijs per gewicht of per verpakkingseenheid worden berekend. De akten bevatten ook de wijze van betaling, de koers van de munt en opgaven van panden en borgen. In de meeste gevallen zijn niet al deze elementen gelijktijdig aanwezig maar door substitutie is het dikwijls mogelijk gebleken de ontbrekende gegevens aan te vullen.

28. Prims, 'De statuten', 16.

29. SAA, SR 1-96 (1394-1480) 96 registers. 


\section{G. ASAERT}

Op 293 opgespoorde contracten betreffen 206 de handel in wede of $70 \%$ van het totaal. Er zijn er 85 voor meekrap en slechts 2 voor de gele kleurstof wouw die dan ook verder onbesproken zal blijven. Een totaal van 293 contracten vormt op het eerste gezicht natuurlijk niet een indrukwekkend aantal. Er werd echter heel wat verhandeld zonder dat tot registratie werd overgegaan. Verder betreffen de te bespreken contracten de interregionale groothandel. Dit blijkt uit de hoge bedragen per contract. Voor de wedecontracten werd een gemiddelde van meer dan $47 \mathrm{lb}$. gro. VI. per contract berekend wat alleszins respectabel is als men overweegt dat dit nagenoeg overeenstemt met achtmaal het jaarloon van een Antwerps arbeider uit die tijd ${ }^{30}$. Anderzijds mag men aannemen dat niet-geregistreerde transacties minder belangrijke bedragen betroffen.

Laten we nu eerst aandacht schenken aan de wedehandel en aan de verkopers van deze kleurstof op de Antwerpse markt.

Uit het cijfermateriaal van tabel I blijkt dat de meeste leveranciers uit het Rijnland kwamen, waar zich tussen Aken en Keulen het reeds genoemde grote produktiegebied uitstrekte. Van 206 contracten betreffen 135, of nagenoeg 2/3, Rijnlandse verkopers. Zij zijn voornamelijk afkomstig uit Keulen en Aken, de twee grote steden in dat gebied, - in Keulen is er nu nog een stadsplein dat Waidmarkt heet en verder uit plaatsen tussen beide steden gelegen, te weten, Bergheim, Duren, Gulik (het huidige Jülich), Kaster (een plaatsje halfweg Bergheim en Grevenbroich) en Grevenbroich zelf. Verder worden nog vermeld Pier, in het land van Gulik, en Betbaer, dat vermoedelijk Bedburg is, tussen Kaster en Bergheim gelegen.

Door dit Rijnlands overwicht namen de andere gebieden een eerder bescheiden positie in. Zeventien contracten betreffen Franse verkopers die afkomstig zijn van Kamerijk, Rijsel, Amiens, Dowaai, Parijs en Valencijn. Gemakkelijkheidshalve wordt Frankrijk in de hedendaagse betekenis gebruikt. Ook van Haspengouw uit bereikte wede de Antwerpse markt. De tien contracten uit dit gewest, veertien als men er Maastricht bijrekent, betreffen verkopers uit Zoutleeuw, Sint-Truiden, Kerkom-bij-St.-Truiden, Tienen en Goidsenhoven bij laatstgenoemde stad gelegen. Verder zijn er nog 21 akten waarin de verkopers Brabanders zijn van Antwerpen, Herentals en Lier. Aangezien men mag aannemen dat in het Antwerpse geen wede werd verbouwd betreft het hier klaarblijkelijk tussenpersonen, zodat deze documenten geen uitsluitsel geven over de herkomst van de wede. Er is één verkoper afkomstig van Doornik en bij 19 akten tenslotte kan de herkomst van de verkoper niet worden vastgesteld. Uit deze opsomming blijkt dus het grote numerieke overwicht van de Rijnlanders. Het zal evenwel nuttig zijn te onderzoeken of het aantal contracten dat betrekking heeft op één produktiegebied in verhouding staat tot de hoeveelheden wede die volgens dezelfde documenten werden verhandeld. De juiste

30. Berekend naar E. Scholliers, Loonarbeid en honger. De levensstandaard in de XVe en XVIe eeuw te Antwerpen (Antwerpen, 1960) 89. 
TABEL I. KOPERS EN VERKOPERS VAN WEDE TE ANTWERPEN (1394-1480), GERANGSCHIKT VOLGENS HUN WOONPLAATS ${ }^{31}$.

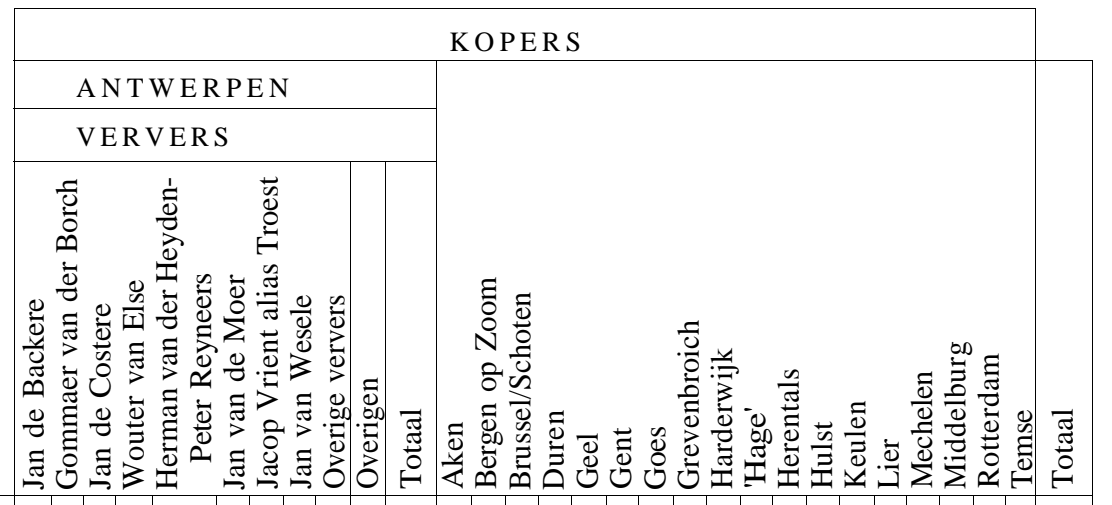

Aken

Amiens

Antwerpen

Bergheim

Betbaer

Doornik

Dowaai

Duren

Goidsenhoven

Grevenbroich

Gulik

Herentals

Kamerijk

Kaster

Kerkem (Tienen)

Keulen

Maastricht

Parijs

Pier

Rijsel

St.-Truiden

Tienen

Valencijn

Zoutleeuw

Niet geïdentificeerd

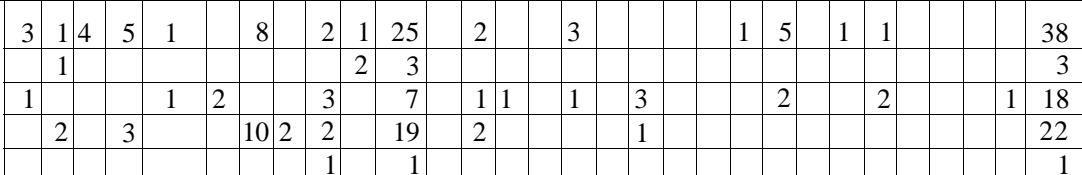

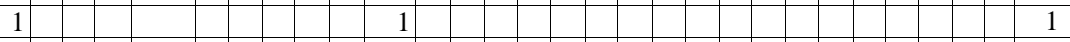

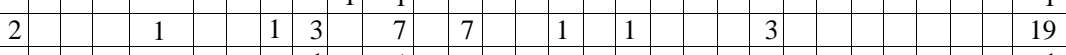

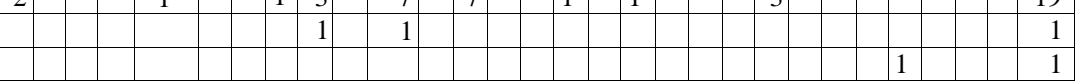

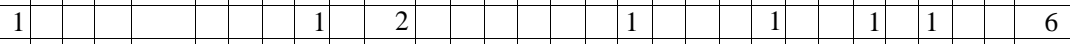

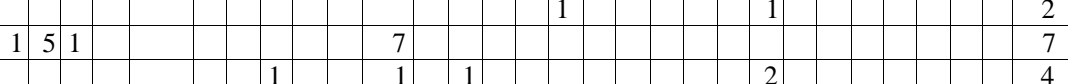

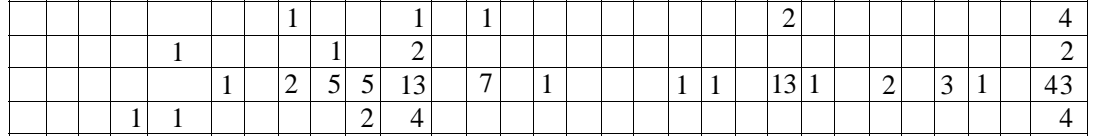

\begin{tabular}{|r|r|l|l|l|l|l|l|l|l|l|l|l|l|l|l|l|l|r|r|}
\hline & 1 & & & & & & & & & & & & & & 1 \\
\hline 1 & & & & & & & &
\end{tabular}

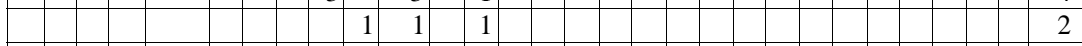

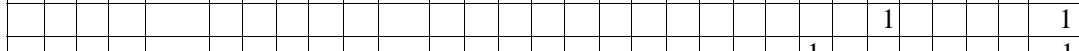

\begin{tabular}{|c|c|c|c|c|c|c|c|c|c|c|c|c|c|c|c|c|c|c|c|c|}
\hline & & & & & & & 2 & 2 & & & & & & & & & 2 & & & 4 \\
\hline & 1 & 1 & & 2 & & 2 & 1 & & 1 & 7 & 1 & & & & 1 & & 2 & & & 19 \\
\hline 10 & \begin{tabular}{|l|l|}
9 & 6
\end{tabular} & 10 & 5 & 5 & & 24 & \begin{tabular}{|l|l}
15 & 1
\end{tabular} & 108 & & 291 & \begin{tabular}{l|l}
1 & 7
\end{tabular} & \begin{tabular}{l|l|}
7 & 1
\end{tabular} & $\begin{array}{lll}6 & 1\end{array}$ & 1 & \begin{tabular}{l|l|l}
1 & 28 & 2
\end{tabular} & $\begin{array}{lll}2 & 1\end{array}$ & 111 & 4 & 1 & 206 \\
\hline
\end{tabular}

31. In deze tabel staan in verticale opstelling de verkopers, alfabetisch gerangschikt volgens hun woonplaats. Hun kopers zijn horizontaal opgesteld, eveneens volgens de woonplaats alfabetisch gerangschikt. De Antwerpse kopers werden echter opgedeeld in ververs en niet-ververs. Van eerstgenoemden worden de meest vermelde ververs apart gerangschikt. Uit deze tabel kan dus worden afgelezen aan welke kopers door de verkopers wede werd verhandeld. Bijvoorbeeld inwoners van Amiens, drie vermeldingen in totaal, verkopen aan de Antwerpse verver Gommaer van der Borch, éénmaal, en tweemaal aan Antwerpse niet-ververs. 


\section{G.ASAERT}

kwantiteit aan wede is echter uit de contracten niet rechtstreeks af te lezen omdat meestal slechts het bedrag dat voor de partij verschuldigd was werd opgegeven en zelden het aantal kuipen of vaten. Wel kan men gaan vergelijken aan de hand van de verschuldigde bedragen.

Samentelling van deze bedragen levert voor de wede uit het Rijnland 6.685.6.7 lb. gro. VI. op of $68 \%$ van alle bedragen. Wij mogen er aan herinneren dat $66 \%$ van de contracten op Rijnlandse verkopers betrekking had.

De contracten met Franse wede belopen 1.272.18.2 lb. of 13\%. Het aantal van deze contracten bedraagt $8,5 \%$.

Uit Haspengouw kwam wede ter waarde van $279 \mathrm{lb}$. of bijna $3 \%$ van het totaal, terwijl 5\% van de contracten Haspengouwse wede betreft. De waarde van de Rijnlandse inbreng overtreft dus nog het numerieke aandeel van de contracten. Voor de zogenaamde Franse contracten ligt dit hoger, voor Haspengouw lager.

Wat de prijzen aangaat werden tussen de drie geciteerde gebieden geen noemenswaardige verschillen aangetroffen. De prijzen lagen grosso modo tussen 1 en $3 \mathrm{lb}$. per kuip, zowel voor de Rijnlandse, de Haspengouwse als voor de Noord-Franse wede. Men kan dus stellen dat de Haspengouwse partijen per contract heel wat kleiner waren dan de Noord-Franse, terwijl de Rijnlandse hier een tussenpositie innamen.

Het is natuurlijk moeilijk, zo niet onmogelijk, om uit te maken of dit Rijnlandse overwicht zou gehandhaafd blijven als men ook de cijfers van de niet-geregistreerde wedehandel zou kennen. Wij hebben echter wel de indruk dat dit het geval kan zijn en het is zelfs niet uitgesloten dat dit Rijnlandse overwicht dan nog sterker zou geaccentueerd worden, rekening houdend met het belang van het verkeer per as langs de zogenaamde Keulse weg en met de sterke aanwezigheid van kooplui uit deze gebieden op de Brabantse jaarmarkten.

Uit het voorhanden zijnde bronnenmateriaal kan alleszins worden afgeleid dat Antwerpen tijdens de vijftiende eeuw een interessante invoer van wede heeft gekend, voornamelijk komend van uit het Rijnland.

Voor wie was nu deze kleurstof bestemd? Deze vraag kan worden beantwoord door in de contracten afkomst en beroep van de kopers nader te gaan onderzoeken.

Het valt bij raadpleging van tabel I onmiddellijk op dat ongeveer de helft van de kopers burgers van Antwerpen waren, nl. in 108 van de 206 contracten. Tweede vaststelling: van deze 108 Antwerpenaars oefenden er 92 het beroep van verver uit. Dit betekent natuurlijk niet dat er te Antwerpen 92 ververs zouden bedrijvig zijn. Dezelfde naam kan meer dan éénmaal voorkomen. Men kan dus alvast stellen dat een groot deel van de wedeinvoer in de plaatselijke ververskuipen terecht kwam. De vreemde wedehandelaars kwamen er hun produkten rechtstreeks aan de consument verkopen. Slechts in enkele gevallen kochten Antwerpse handelaars de wede op. De 92 contracten met Antwerpse ververs als kopers van wede betreffen in werke- 
lijkheid 21 verschillende personen. Uit deze getallen blijkt dadelijk dat de meesten slechts in enkele contracten voorkomen. Slechts 4 ververs werden 9 maal of meer aangetroffen, nl.:

Jacob Troest alias Vrient, 18 contracten van 1458 tot 1473

Jan de Backere, $\quad 10$, , , 1448,1466

Wouter van Else, $\quad 10 \quad, \quad, \quad, 1471$, , 1478

Gommaer van der Borch, 9 , , , , 1455 , 1460

Jacob Troest komt dus 18 maal voor op 16 jaar tijds. Hij kocht voor $315.10 .8 \mathrm{lb}$. gro. VI. of een gemiddelde van meer dan $17 \mathrm{lb}$. per contract. Per contract kocht hij, in zover opgegeven, van 8 tot 20 kuipen, voor een waarde begrepen tussen 13 en 33 lb. gro. VI. Deze verver werd slechts door drie wedehandelaars, allen Rijnlanders, van kleurstof voorzien. Dit is natuurlijk geen algemene regel.

Jan de Backere heeft een gekende bedrijvigheid van 19 jaar. In totaal kocht hij voor 311.14.6 lb. gro. VI. of gemiddeld $33 \mathrm{lb}$. per contract, aanzienlijk hoger dan het gemiddelde van Jacob Troest. De waarde van de partijen wede ligt bij De Backere tussen 12.1 .8 en $641 / 2$ lb. gro. VI. Deze verver kocht grotendeels bij Rijnlanders maar liet zich ook door een koopman van Kamerijk en door één van Doornik bevoorraden.

Van Wouter van Else zijn eveneens 10 contracten bewaard gebleven die slechts een periode van 8 jaar omvatten. Zijn totale aankoopsom bedraagt 424.-.9 lb. gro. VI., dat is een bijzonder hoog gemiddelde van ca. $42 \frac{1}{2} \mathrm{lb}$. De leveranciers waren, op een Maastrichtenaar na, Rijnlanders.

Tenslotte heeft Gommaer van der Borch een bedrijvigheid van 6 jaar gedemonstreerd. Tijdens deze periode sloot hij 11 wedecontracten af voor een totaal bedrag van $356.14 .2 \mathrm{lb}$. gro. VI., gemiddeld ca. $32 \mathrm{lb}$. per contract. In tegenstelling tot de drie hogervernoemde ververs was Van der Borch afnemer van wedekooplui van Kamerijk (7 contracten) en van Amiens (1 contract). De laatste leverancier was een Rijnlander.

De Antwerpse ververs waren ambachtelijk gegroepeerd in een eigen lakenverversambacht. Zij waren gevestigd bij de stadsvlieten die aan het spel van eb en vloed onderhevig waren. Ververs hadden immers stromend water in grote hoeveelheden nodig. Reeds op het einde van de dertiende eeuw was er te Antwerpen een Platea tinctorum die in de veertiende eeuw verdietst werd tot Verversruye, gelegen bij de Grote Markt, thans Kaasrui ${ }^{32}$. In de vijftiende eeuw bleven er ververs op deze plaats gevestigd maar de meesten zwermden uit langs de ruien naar het noordoostelijk stadsdeel, daar waar het nieuwe centrum van de lakenbereiding tot ontwikkeling kwam. Uit het tiental vermeldingen van ververijen in de bronnen blijkt dat vooral het gebied omschreven als 'buiten de Koepoort' door de ververs als

32. F. Prims, 'De eerste eeuw van de lakennijverheid te Antwerpen (1226-1328)', Antwerpsch Archievenblad, 2e reeks, III (1928) 138. 
vestigingsplaats werd verkozen. Daar lag immers ook een rui, en in straten als Dries en Goddaert, verder ook op de Voldersvest, op de hoek van de Keizerstraat en meer naar het zuiden bij de binnenste Kipdorppoort waren ververs gevestigd ${ }^{33}$. In de zestiende eeuw schoven zij met de groeiende stad steeds verder naar de periferie op. De Verversrui is een nog bestaande straatnaam die blijft herinneren aan de ververs eens in deze omgeving gevestigd ${ }^{34}$.

De niet-ververs die wede kochten waren handelaars, ook wel eens mensen uit de textielindustrie, zoals een lakenbereider, een droogscheerder of een wolwever. Tot zover de Antwerpse kopers die, zoals gezegd, in 108 van de 206 contracten voorkomen.

De 98 overblijvende contracten noemen kopers uit andere steden die zich op de Antwerpse markt kwamen bevoorraden. Uit welke plaatsen waren zij afkomstig? In de eerste plaats uit Bergen-op-Zoom. De geschiedenis van de meekrap in die stad is onderzocht ${ }^{35}$; ons ontbreekt echter een studie over handel en verbruik van weed daar. Zonder op een eventueel onderzoek te willen vooruitlopen lijkt ons de meekraphandel daar toch van meer belang te zijn geweest. Alleszins zijn er Bergenaars die zich te Antwerpen in wede kwamen bevoorraden. Zij komen in 29 contracten voor, gevolgd door mensen uit Herentals (28 contracten), Lierenaars (11 contracten) en inwoners van Geel (7 contracten). De drie laatstgenoemde plaatsen zijn kleinere Brabantse draperiesteden in de buurt van Antwerpen. Zowel Herentals als Lier en Geel behoorden tot Kempense centra waar de lakennijverheid sedert de tweede helft van de veertiende eeuw een merkwaardige opgang kende ${ }^{36}$. Kopers uit deze steden zijn vrijwel altijd ververs (in Bergen-op-Zoom, 28 op 29, in Lier, 10 op 11 en in Geel, 7 op 7; alleen betreffende Herentals werden slechts 12 ververs

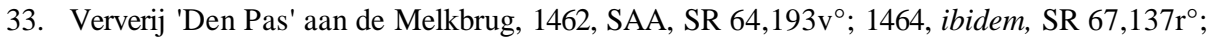
1470, ibidem, SR 76, 420 $\mathrm{r}^{\circ}$; 1479, ibidem, SR 95, 249r'. Ververij 'De drie Coningen', buiten de Koepoort, 1474, ibidem, SR 83,176v $\mathrm{v}^{\circ} ; 1478$, ibidem, SR 94, 224r $\mathrm{r}^{\circ}$. Een eeuw later, in 1572, is hier nog steeds een ververij gevestigd, cf. A. K. L. Thijs, 'Bronnen voor de nijverheids- en familiegeschiedenis. De Antwerpse lakenververs 1563-1583', Vlaamse Stam, V (1969) 46. Ververij 'De Colve', buiten de Koepoort, 1455, ibidem, SR 50, 395v'. Ververij 'Coelne', buiten de Koepoort, 1462, ibidem, SR 64, 185r'. Ververij 'Den Eenhoren', buiten de Koepoort, 1473, ibidem, SR 82, $267 \mathrm{v}^{\circ}-268 \mathrm{r}^{\circ}$; 1473, ibidem, SR 82,'298 $\mathrm{r}^{\circ}$. Ververij buiten de Koepoort, 1440, ibidem, SR 28, 57 $\mathrm{v}^{\circ}$. Ververij buiten de Koepoort, 1431, ibidem, SR 17, 96r ${ }^{\circ}$. Ververij op de Voldersvest, hoek Keizerstraat, 1473, ibidem, SR 83,111 r ${ }^{\circ}$. Ververij op de Rui bij de Koepoort, 1457, ibidem SR 54. $31^{\circ}$. Ververij 'Leeuwensteyne' aan de Goddaert, 1456, ibidem, SR 52,189r ${ }^{\circ}$; 1462 , ibidem, SR 64,231 ${ }^{\circ}$ $\mathrm{v}^{\circ}$. Ververij buiten de Koepoort bij de straat naar den Dries, 1464, ibidem, SR 67,135 $\mathrm{v}^{\circ}$. Ververij buiten de binnenste Kipdorppoort op de vest naar de St.-Kathelijnepoort, grenzend aan de Kipdorpstraat, 1465 , ibidem, SR $68,90 \mathrm{v}^{\circ}$.

34. Cf. Thijs, 'De Antwerpse lakenververs', 37-46; idem, 'Antwerpse ververs uit Rijsel (16e eeuw)', Vlaamse Stam, V (1969) 125-135.

35. C. Slootmans, 'Meekraphandel op de jaarmarkten van Bergen-op-Zoom', De Ghulden Roos, XVIII (1958).

36. H. van der Wee, The Growth of the Antwerp Market and the European Economy (fourteenthsixteenth Centuries), II ('s-Gravenhage, 1963) 10. 
op 28 kopers teruggevonden; het wil ons evenwel voorkomen dat het toevallig ontbreken van de beroepsopgave dit cijfer sterk heeft beïnvloed). Andere kopers van wede te Antwerpen kwamen uit Goes met 6 contracten waarvan 3 van ververs, en uit Middelburg met 4 contracten waarvan 3 met de in die stad residerende Schotse koopman Robert Colden als koper. De aantrekkingskracht van de Antwerpse markt op dit terrein komt verder tot uiting door de aanwezigheid van kopers uit Hulst ( 2 contracten) en verder telkens met één vermelding uit Brussel, Gent, Harderwijk, Mechelen, Rotterdam, Temse en Hage ${ }^{37}$.

Het is beslist onmogelijk zich een idee te vormen van het volume van de wedeimport in het vijftiende-eeuwse Antwerpen. Het lijdt immers geen twijfel dat ook niet-geregistreerde partijen werden ingevoerd. Zelfs aan de hand van de hier besproken contracten blijft een taxatie van kwantiteiten uiterst moeilijk omdat in vele gevallen vermelding van de hoeveelheid ontbreekt. In geval van opgave werd de kwantiteit aan wede in de hier behandelde contracten uitgedrukt in kuipen. Als kleinere maat werd ook wel het vat of de ton vermeld ${ }^{38}$. Het vat (ton) is een verpakkingseenheid zodat geen precieze inhoud kan worden berekend ${ }^{39}$. De kuip is de recipiënt die zich in de ververij bevindt en die eveneens van atelier tot atelier verschillende inhouden kan vertonen. Een exacte constante verhouding tussen kuip en vat bestaat bijgevolg niet. Wel hebben wij getracht een aproximatieve relatie tussen beide te berekenen ${ }^{40}$.

De baal hebben wij als verpakkingseenheid voor wede in de opgespoorde contrac-

37. Vermoedelijk Hage bij Roosendaal. Mogelijk de residentie of Ter Hage in Zeeuws-Vlaanderen.

38. Slechts in twee gevallen wordt de kwantiteit uitgedrukt in pijpen wede, SAA, SR $31,98 \mathrm{v}^{\circ}$ en SR $56,19 \mathrm{v}^{\circ}$. Doorgaans stelt men de pijp, een langwerpig houten recipiënt, gelijk aan $1 / 2$ vat. Cf. $\mathrm{H}$. Doursther, Dictionnaire universel des poids et mesures anciens et modernes (Amsterdam, 1965) $430 \mathrm{vlg}$.

39. In Bordeaux weegt 1 ton wede $600 \mathrm{~kg}$, in Nantes slechts $150 \mathrm{~kg}$., ibidem, 556 .

40. In een contract van 1438 (SAA, SR 25, 520v') kosten 71 kuipen en 1 vat wede 854 Rijnsgulden, terwijl de prijs van 1 kuip op 12 Rijnsgulden wordt vastgesteld. Een eenvoudige berekening toont aan dat de 71 kuipen kosten: 71 x 12 Rijnsgulden $=852$ Rijnsgulden. Van de 854 Rijnsgulden blijven er bijgevolg 2 Rijnsgulden over, zijnde de prijs van 1 vat. De prijs, zowel van de kuip als van het vat, in een en hetzelfde contract, is dus gekend, nl. 12 Rijnsgulden voor 1 kuip en 2 Rijnsgulden voor 1 vat, of een verhouding 6:1. De kuip kan in dit voorbeeld dus 6 vaten bevatten.

In een contract van 1473 (ibidem, SR 81, 233r ${ }^{\circ}$ ) kosten 22 kuipen en 3 vaten wede 249 Rijnsgulden 15 stuiver. De koers van de Rijnsgulden, zoals vastgesteld in dit contract, bedraagt 20 stuiver. Vijftien stuiver zijn hier dus gelijk aan 0,75 Rijnsgulden, zodat de totale prijs 249J Rijnsgulden beloopt. Volgens een bepaling van het contract wordt de prijs van de kuip op 11 Rijnsgulden vastgesteld. Bijgevolg kosten 22 kuipen wede: 22 x 11 Rijnsgulden $=242$ Rijnsgulden. Drie vaten wede kosten: $(249,75-242)$ Rijnsgulden $=7,75$ Rijnsgulden. Eén vat wede kost: 7,75 Rijnsgulden

3

1 kuip ca. 4 vaten kan bevatten. 


\section{G. ASAERT}

ten niet ontmoet. In de zestiende eeuw evenwel gingen er te Antwerpen 8 balen in een ton $^{41}$. Dit stemt verder overeen met teksten door Sneller en Unger gepubliceerd $^{42}$. In het zestiende-eeuwse Engeland daarentegen gingen er slechts 5 balen Toulouser pastel van 200 pond in 1 ton $^{43}$. Maar wat de Nederlanden betreft mag men dus wel de baal op 1/8 ton stellen. Rekening houdend met onze berekeningen betreffende de verhouding kuip-vat, waarbij de inhoud van de kuip op 4 à 6 vaten werd gesteld, gemiddeld 5 vaten, kan 1 kuip 5 x 8 of gemiddeld 40 balen wede bevatten. Resumerend komen we dan tot volgende aproximatieve verhoudingen tussen kuip, vat en baal:

1 kuip $=5$ vaten of tonnen $=40$ balen.

1 ton of vat $=8$ balen $=1 / 5 \mathrm{kuip}$.

1 baal $=1 / 8$ ton $=1 / 40$ kuip.

Hoger werd gesteld dat de grootte van de weedinvoer in het vijftiende-eeuwse Antwerpen bezwaarlijk kon worden vastgesteld. Wij moeten ons tevreden stellen met de contracten die voorhanden zijn. Van de 206 wedecontracten werd slechts in 60 de kwantiteit aan wede in kuipen uitgedrukt. Wanneer men het aantal kuipen samentelt bekomt men 1.699 kuipen of gemiddeld 28 kuipen per contract. Op 206 contracten zou dit bij eenzelfde gemiddelde 5.833 kuipen opleveren, of gezien voor de periode van 87 jaar, 67 kuipen per jaar.

Voor twee jaren is het mogelijk gebleken de import uit de contracten te berekenen. Men verwarre deze niet met de reële jaarlijkse invoer, die ongetwijfeld hoger ligt. In 1450 werden 115 kuipen geïmporteerd of 23 kuipen per transactie. In 1443 werden 7 wede contracten voor de schepenbank geregistreerd. Van 6 is de hoeveelheid wede in kuipen aangegeven, nl. $25+30+50+12+45+18=180$ kuipen, gemiddeld 30 kuipen per contract. De zevende minuut van de schepenbrief vermeldt een aankoop van wede ten bedrage van 675 Rijnsgulden. Dit kan overeenstemmen met ca. 42 kuipen $^{44}$. De totale weedinvoer in 1443 bedraagt dan $180+42=222$ kuipen weed. De metrieke waarde van de kuipinhoud wordt volgens Joris ${ }^{45}$ gesteld op 280 à 300 kg. blijkens een passage in Pegolotti's ${ }^{46}$ Pratica della Mercatura. Hier is echter enig voorbehoud gewettigd. Pegolotti verbleef wel gedurende korte tijd te Antwerpen maar is geen tijdgenoot. Hij schreef omstreeks 1342, en het type van ververs-

41. Craeybeckx, Un grand commerce, 145, noot 282.

42. Sneller en Unger, Handel met Frankrijk, nrs. 462(1502)-463(1502): 8 balen wede $=1$ ton; nrs. 404(1494), 457(1502): 71/2 balen wede $=1$ ton. Geciteerd door Craeybeckx, Un grand commerce, 145 , noot 282; W. S. Unger, De tol van Iersekeroord. Documenten en rekeningen 1321-1572. RGP, Kleine Serie XXIX ('s-Gravenhage, 1939) 123(1520).

43. T. S. Willan, A Tudor Book of Rates (Manchester, 1962) 64.

44. 1 kuip gerekend à 16 Rijnsgulden, een normale prijs.

45. A. Joris, 'Les moulins à guède dans le comté de Namur pendant la seconde moitié du XIIIe siècle', Le Moyen Age, LXV (1959) 269-270.

46. F. Pegolotti, La Pratica della Mercatura, A. Evans, ed. (Cambridge, Mass., 1936) 238. Geciteerd bij Joris, 'Les moulins à guède', 269, noot 68. 
kuip dat hem voor ogen stond is dat van Brugge, wat niet noodzakelijk met het Antwerpse overeenstemt.

Bij gebrek aan beter vergelijkingsmateriaal aanvaarden we noodgedwongen een kuipinhoud van $300 \mathrm{~kg}$. Volgens de verhoudingen, hoger berekend, weegt 1 vat dan $60 \mathrm{~kg}$., wat aanvaardbaar is met het oog op manipulatie. De baal weegt dan ca. $7 \mathrm{~kg}$. De jaarlijkse aanvoer, geregistreerd voor de stadsschepenen, beliep dan in 1443: 222 kuipen à $300 \mathrm{~kg}$. = $66.600 \mathrm{~kg}$. en in 1450: $115 \mathrm{kuipen} \mathrm{à} 300 \mathrm{~kg}$. $=34.500 \mathrm{~kg}$. In balen geeft dat, de kuip gerekend à 40 balen, 8.080 balen in 1443 en 4.600 balen in 1450. Wanneer we deze cijfers, die alleen de geregistreerde weedimport betreffen, gaan vergelijken met de 40.000 balen die volgens Guiccardini in de zestiende eeuw jaarlijks te Antwerpen werden ingevoerd ${ }^{47}$, dan ligt de zestiende-eeuwse import van 5 tot 9 maal hoger, een verhouding die wel aannemelijk is maar helaas niet controleerbaar. Het is bekend dat de Grote Watertol voor de periode 1445-1450 verpacht werd voor 206.400 gro. VI. en dat in het midden van de zestiende eeuw de ontvangsten 905.615 gro. VI. ${ }^{48}$ beliepen wat een verviervoudiging betekent. Er zij nochtans opgemerkt dat de collecte van 1445-1450 niet gekend is, zodat ook aan deze vergelijking wat schort.

Wij willen met nadruk onderlijnen dat voornoemde gegevens slechts bepaalde aanwijzingen kunnen opleveren. Te veel elementen in onze berekeningen missen een stevige basis, zodat het nodige voorbehoud dient te worden gemaakt. Wij hebben nochtans gemeend de lezer deze cijfers niet te mogen onthouden.

Wat de aanvoerwegen betreft werd weed uit het Rijnland over de landweg naar Antwerpen gebracht en dat zal ook wel voor het Haspengouwse produkt het geval zijn geweest. De wede uit Noord-Frankrijk kwam langs de waterweg en hier ligt ons inziens een verklaring voor de grotere partijen per contract uit dit gebied verstuurd. Een schipper van Gent getuigde in 1432 dat hij sedert 35 jaar, dat is dus van voor de eeuwwisseling, naar Antwerpen voer met koren en wede hem toevertrouwd door kooplui van Bethune, Valencijn, Rijsel, Doornik en andere niet gespecificeerde steden $^{49}$. In het fragmentaire toltarief van Iersekeroord van oktober 1444 moest wede worden ingeklaard a 8 gro. per vat, die van Amiens à 12 gro. per vat ${ }^{50}$. Antwerpse schepen voeren in die tijd geregeld naar de Somme en het is niet onwaarschijnlijk dat wede tot hun retourvracht behoorde.

Anderzijds verscheepte men wede die te Antwerpen verhandeld was over de Schelde-Honte zeewaarts. Ook hiervan treft men in de tolrekeningen van Iersekeroord,

47. Dit cijfer zou op de periode na 1560 betrekking hebben: Coornaert, Les Français, II, 104, noot 6 .

48. Van der Wee, The Growth of the Antwerp Market, I, 512, 516.

49. Proces tusschen Antwerpen, Brussel en Mechelen - Stapel van zouten, visch, haver, enz., 1432, SAA, tolkamer $584,245 \mathrm{r}^{\circ}$. Getuigenis van Lauwerijs van der Eeke, ca. 50 jaar oud, schipper van Gent.

50. Unger, De tol van Iersekeroord, 11. 


\section{G. ASAERT}

zij het sporadisch, sporen aan, onder meer in 1418. Een schipper van Brugge heeft dan 16 kuipen wede aan boord die te Antwerpen in de Pinksterjaarmarkt werden geladen $^{51}$. Ook ging Rijnlandse wede over Antwerpen naar Engeland. In 1466 bevrachtten drie Keulse kooplieden 9 vaten wede en ander goed op een schip van Bergen-op-Zoom. De lading werd te Antwerpen, tijdens de Pinksterjaarmarkt aan boord genomen met bestemming Colchester. Daar leed het vaartuig schipbreuk en de goederen spoelden aan op Sheppey ${ }^{52}$.

In Antwerpen werd de wede gemeten door de vrije turfdragers en door de onvrije buideldragers in de stad vervoerd. Dezen kregen in 1447 monopolie voor transport van turf en houtskool, in bijkomende orde van wede, een toestand die tot het begin van de zestiende eeuw onveranderd zou blijven ${ }^{53}$. De correlatie turf dragers-ververs kan worden verklaard door het grote turfverbruik van de ververs voor het heten van hun ketels. Tot zover de wedehandel.

Wat nu de meekrap betreft valt in eerste instantie het kleiner aantal contracten op, slechts 85 tegenover 206 voor wede. Een verklaring ligt voor de hand: vele lakens kregen eerst een blauwe grondkleur. Ook waren blauw en zwart de meest gewilde kleuren, onder andere bij de geestelijken, voor rouwklederen, en ook bij het gewone volk, zodat er meer vraag was naar de blauwe verfstof wede dan naar de rode meekrap.

Wie kwam de mede op de Antwerpse markt te koop stellen? Het is bekend dat Zeeland in de vijftiende eeuw en ook nog lange tijd daarna het belangrijkste teeltgebied in Europa is geweest, met Zierikzee als grote markt. Men mag dus geredelijk verwachten dat heel wat Zeeuwen als verkopers fungeerden. Dat is echter in veel geringere mate het geval dan men zou vermoeden, zoals uit de volgende tabel blijkt.

Uit het cijfermateriaal van tabel II kan men aflezen dat een grote meerderheid van 58 verkopers op 85 alvast van niet-Zeeuwse origine was, nl. 28 Antwerpenaars, 22 Bergenaars en 8 mensen van Lillo. Verkopers uit Chaam, Halsteren en Steenbergen brengen het aantal verkopers uit het oude hertogdom op 61. Het aantal Zeeuwse verkopers, met mensen van Reimerswaal, Goes, Tholen, Schakerlo, Zierikzee, Middelburg, Kortgene, Biezelinge, Crompvliet en Emelissen, bedraagt slechts 14. Verder zijn er 2 Vlamingen uit de Vier-Ambachten.

De Antwerpse verkopers van mede of meekrap waren over het algemeen kooplieden. Waarschijnlijk kwamen hun produkten uit de Antwerpse polders. Ook Bergen-op-Zoom lag, nog meer dan Antwerpen, temidden van meekrapcultures.

51. Ibidem, 199.

52. H. J. Smit, Bronnen tot de geschiedenis van den handel met Engeland, Schotland en Ierland, I, RGP, Grote Serie LXVI ('s-Gravenhage, 1928) nr. 1. 558.

53. Prims, Turfdragersambacht, xi, 81-82. 
TABEL II. GEOGRAFISCHE VERDELING VAN DE KOPERS EN VERKOPERS VAN

85 MEDECONTRACTEN, VERLEDEN VOOR SCHEPENEN VAN ANTWERPEN, 1405-1480.

\begin{tabular}{|c|c|c|c|c|c|c|c|c|c|c|c|c|c|c|c|c|c|c|c|c|}
\hline & & & & & & & & $\mathrm{KC}$ & $P$ & $R$ & & & & & & & & & & \\
\hline & & 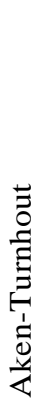 & $\begin{array}{l} \\
\\
0 \\
0 \\
0 \\
0 \\
0 \\
0 \\
0 \\
0 \\
\end{array}$ & 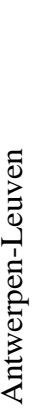 & 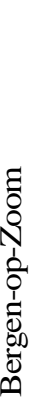 & 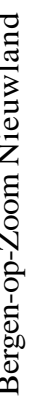 & & $\frac{\vec{d}}{2}$ & & $\begin{array}{l}\frac{\pi}{0} \\
\frac{D}{0} \\
0\end{array}$ & 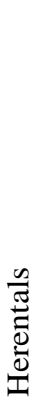 & $\overline{\mathbb{O}}$ & 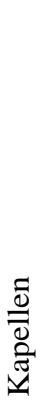 & 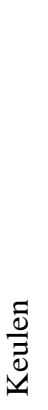 & & 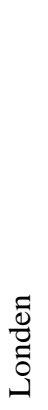 & $\stackrel{\varrho}{\equiv}$ & 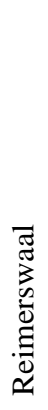 & $\begin{array}{l} \\
\overrightarrow{0} \\
\overline{0} \\
\frac{\tilde{v}}{0} \\
\frac{0}{0} \\
0\end{array}$ & 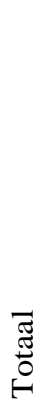 \\
\hline & Antwerpen & 1 & 18 & 1 & 1 & 1 & 1 & & & & 1 & & & 1 & 1 & & 1 & 1 & & 28 \\
\hline & Antwerpen-Reimerswaal & & & & & & & & & 1 & & & & & & & & & & 1 \\
\hline & Bergen-op-Zoom & & 11 & & 5 & & & & 1 & & 1 & 1 & & 1 & . & 1 & & & 1 & 22 \\
\hline & Biezelinge & & & & & & & & & & & & & & 1 & & & & & 1 \\
\hline & Chaam & & 1 & & & & & & & & & & & & & & & & & 1 \\
\hline & Crompvliet & & 1 & & & & & & & & & & & & & & & & & 1 \\
\hline$\frac{\alpha}{I}$ & Emelissen & & 1 & & & & & & & & & & & & & & & & & 1 \\
\hline 2 & Engeland & & 1 & & & & & & & & & & & & & & & & & 1 \\
\hline 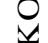 & Goes & & 2 & & & & & & & & & & & & & & & & & 2 \\
\hline$\underline{\underline{\alpha}}$ & Halsteren & & 1 & & & & & & & & & & & & & & & & & 1 \\
\hline II & Hulst & & 1 & & & & & & & & & & & & & & & & & 1 \\
\hline & Kortgene & & & & 1 & & & & & & & & & & & & & & & 1 \\
\hline & Lamswaarde & & & & 1 & & & & & & & & & & & & & & & 1 \\
\hline & LiUo & & & & 4 & & & 4 & & & & & & & & & & & & 8 \\
\hline & Maastricht & & & & & & & & & & & & & 1 & & 1 & & & & 2 \\
\hline & Middelburg & & 1 & & & & & & & & & & & & & & & & & 1 \\
\hline & Reimerswaal & & 1 & & 2 & & & & & & & & & & & & & & & 3 \\
\hline & Schakerlo & & 1 & & & & & & & & & & & & & & & & & 1 \\
\hline & Steenbergen & & 1 & & & & & & & & & & & & & & & & & 1 \\
\hline & Tholen & & 2 & & & & & & & & & & & & & & & & & 2 \\
\hline & Zierikzee & & 1 & & & & & & & & & & & & & & & & & 1 \\
\hline & Onbekend & & 1 & & & & & & & & & & 1 & & 1 & & & & 1 & 4 \\
\hline & & 1 & 45 & 1 & 14 & 1 & 1 & 4 & 1 & 1 & 2 & 1 & 1 & 3 & 3 & 2 & 1 & 1 & 2 & 85 \\
\hline
\end{tabular}

De sterke aanwezigheid van inwoners uit de Zoomstad ligt dan ook voor de hand. Deze gedachte geldt ook voor Lillo, in de Antwerpse polders gelegen ${ }^{54}$.

Inzake aankoop van meekrap waren de Antwerpenaars de actiefsten. In deze 85

54. R. Havermans, 'Historisch-geografische sprokkelingen uit het Antwerpse polderland', LX, 'De meekrapstoven in onze polder'(S.1., 1967) 1.208-1.220, getypte documentatiemappen in SAA, Archieven van polders, nr. 276. 


\section{G. ASAERT}

contracten traden zij niet minder dan 45 maal als koper op. Naast kooplui waren het voornamelijk ambachtslui uit de textielbranche die zich van mede voorzagen, (linnenwevers, droogscheerders en wolwevers). Opvallend is het ontbreken van ververs $^{55}$. De weedverwerkende ververs, met andere woorden de blauwververs, kwamen in deze contracten niet voor. Blijkbaar was de scheiding tussen blauw- en roodververs reeds een feit geworden en was de Antwerpse ververij vooral op het blauwverven gericht.

Naar de gewoonte van de tijd zijn ook lieden die ogenschijnlijk niets met deze meekraphandel te maken hebben wel eens opkoper van een partijtje. Dat geldt bijvoorbeeld voor een korenkoper, een smid, een smoutslager en een schipper. Van de andere Brabantse steden trad Bergen-op-Zoom ook hier sterk op de voorgrond met 14 kopers. De andere plaatsen (en we denken aan de kleinere draperiesteden zoals Herentals, Lier en Geel, die voor de wedehandel sterke commerciële bindingen met Antwerpen hadden) kwamen hier bijna niet aan bod. Er waren slechts 2 kopers uit Herentals. Verder was er 1 uit Turnhout (samen met een Akenaar), 1 uit Pulle, Breda, Kapellen, 1 uit Leuven (samen met een Antwerpenaar), en 3 uit Lillo. De ververs uit de Kempen, indien zij veel rode verfstoffen verbruikten, betrokken deze blijkbaar niet over Antwerpen, en evenmin over Bergen-op-Zoom ${ }^{56}$.

Als schakel met het binnenland schijnt de rol van Antwerpen op dit gebied weinig belangrijk. Het aantal kopers van meekrap afkomstig uit verder afgelegen streken is zeer gering: er waren 3 Keulenaars en telkens 1 koper uit Duren en uit Hoei. Verder waren er 4 uit Biervliet en 1 uit Reimerswaal en uit Nieuwenlande in Zeeland, en verder nog 2 niet identificeerbaren. Tenslotte waren er 3 Engelsen die te Antwerpen meekrap kwamen opkopen. Engeland was in de vijftiende eeuw een grote importeur van Zeeuwse meekrap. Tijdens zes maanden van 1450 werden 409 balen mede uit de Nederlanden in Engeland aan wal gezet ${ }^{57}$. Van dit totaal werden 46 balen of $11 \%$ uit Antwerpse schepen gelost ${ }^{58}$. Tijdens de eerste acht maanden van 1446 werden er $588 £$ baal ingevoerd, waarvan 49 balen of bijna $8 \%$ aan boord van Antwerpse vaartuigen. Hier dient echter opgemerkt dat de kwantiteit door de Antwerpenaars in hun thuishaven geladen niet kan worden vastgesteld.

Het is vast niet uitgesloten dat een deel van dit volume door de Antwerpenaars op de Walcherse rede werd geladen. Ook in Bergen-op-Zoom namen Antwerpse vaartuigen mede in hun ruim en wel met Franse bestemming. In 1483 voerde de Antwerpse schipper Luyc Contman, voor rekening van een Antwerpenaar en van

55. Slechts één Antwerpse verver, Jacob Vrient.

56. Slootmans, 'Meekraphandel'.

57. Thieletnans, Bourgogne et Angleterre, 234.

58. G. Asaert, De Antwerpse scheepvaart in de XVe eeuw. Bijdrage tot de ekonomische geschiedenis van de stad Antwerpen, Koninklijke Academie voor Wetenschappen, Letteren en Schone Kunsten van België, Klasse der Letteren XXXV, nr. 72 (Brussel, 1973) 265-266. 
een poorter van Reimerswaal onder meer 22 balen mede naar Rouen ${ }^{59}$. In 1489 lichtte de Antwerpse schipper Gielis Dijcstraet te Bergen-op-Zoom het anker om mede naar de Somme te transporteren ${ }^{60}$.

Dat ook van Antwerpen uit dergelijke transporten bestonden blijkt uit een stuk van 1407. Jean Bonnier, factor van de Bretonse koopman Michel Dutot, kocht op de Antwerpse jaarmarkt 24 balen mede die hij langs de waterweg naar het Zwin zond, met de bedoeling deze partij vervolgens over land naar het hertogdom (Bretagne) te laten voeren ${ }^{61}$.

Voor de invoer van meekrap geldt dezelfde opmerking als voor de wedeimport: het is onmogelijk de omvang te berekenen. Meer dan waarschijnlijk ligt het aandeel van de niet-geregistreerde handel hier hoger dan bij de weed. De cultuurgebieden bevonden zich immers veel dichter bij en zelfs onder de muren van de stad wat tot gevolg had dat de noodzaak om contracten op te stellen niet zo dwingend was.

Bij de levering van mede en meekrap wordt het volume uitgedrukt hetzij in gewichtsponden, hetzij in de verpakkingseenheden vat en baal. Het gewicht per vat en per baal kan worden berekend ${ }^{62}$. Wij zouden durven voorop zetten dat er ca. 40 vaten in een baal mede gaan en dat een vat ongeveer 18 pond weegt.

59. 11 mei 1483, Stadsarchief Bergen-op-Zoom, R 391, $133 \mathrm{v}^{\circ}$.

60. 27 december 1489, Slootmans, 'Meekraphandel', 60.

61. H. Touchard, Le commerce maritime breton d la fin du moyen üge (Parijs, 1967) 149.

62. Mede kost per vat 24 a 29 gro. VI., zijnde de laagste en hoogste prijs die werd teruggevonden. Dit vertegenwoordigt een gemiddelde van 26 i gro. VI. per vat. Honderd pond mede kost 114 a 180 gro. VI. Het is mogelijk maar niet zeker dat de medeprijs per 100 pond iets goedkoper uitvalt. Honderd pond mede gaan dus in $-\frac{147}{26,5}=5$ à 6 vaten. Het gewicht van 1 vat bedraagt bijgevolg: 100 pond $1: 5$ à $6=$

ca. 18 pond. Via 2 contracten is het mogelijk bij benadering het gewicht van een baal

mede te berekenen. In 1471 wegen 7 balen 5.152 pond. Een baal 5.152:7= 736 pond

(SAA, SR 79, $114 \mathrm{v}^{\circ}$ ). In een tweede contract van hetzelfde jaar kosten 7 balen $32 \mathrm{lb}$. gro. VI. of 7.680 groten. Hiervan zijn er 6 balen meekrap die $11 \mathrm{s.} 6$ d. (138 gro.) per 100 pond kosten en 1 baal gewone mede a 9 s. 6 d. (114 gro.) per 100 pond (SAA, SR 80, 32r ${ }^{\circ}$ ). In de 7.680 gro. van de totale som gaan 138 gro. x $48=6.524$ gro. en 114 gro. x $8=912$ gro. of samen 7.436 gro., met een overschot van 244 gro. De verhouding tussen beide soorten verfstof 6:1 wordt dus 4.800:800, of 5.600 pond voor 7 balen. Per baal bekomen we dan een gewicht van 800 pond. Dit is een cijfer dat ook door H. J. Smit wordt opgegeven. (Smit, Bronnen handel met Engeland, Schotland en Ierland, nrs. 1.889,1.794. Hier ook 1.000 pond Bergens gewicht.) Bij A. Schulte wegen 4 balen 3.066 pond in 1478, of 766,5 pond per baal (Geschichte der grossen Ravensburger Handelsgesellschaft, II (Wiesbaden, 1964), 149). Rekening houdend met de twee door ons berekende gevallen, 736 en 800 pond opleverend voor 1 baal mede (meekrap) en het vat gerekend à 18 pond, gaan er 40 à 44 vaten in één baal. Dit resultaat kan enigszins worden gecontroleerd door de gemiddelde prijzen van 1 vat mede en 1 baal mede met elkaar te vergelijken. Mede kost per baal van 576 gro. VI. tot 1.476 gro. VI., dit is een gemiddelde van 1.026 gro. VI., Als we dit delen door de gemiddelde prijs van 1 vat, nl. 26 gro. VI., dan bekomen we als quotiënt 39. Deze oplossing is aanvaardbaar rekening houdend met de onvolkomen gegevens waarover we beschikken. 
Een belangrijk punt dat tot dusver onbesproken bleef is de spreiding van de contracten in de tijd, zowel voor wede, als voor meekrap. De 291 contracten inzake kleurstoffen (wede 206, mede 85) zijn het resultaat van een onderzoek dat zich over een periode van 87 jaar uitstrekt (1394-1480). De bron waaruit werd geput bleef voor genoemde periode nagenoeg volledig bewaard ${ }^{63}$. Bij gelijke spreiding zou ieder jaar slechts ca. 3 contracten opleveren. In werkelijkheid zijn er periodes, vooral in het begin van de vijftiende eeuw, waarin geen wede- of meekrapcontracten werden afgesloten, andere jaren zoals 1442 en 1459 geven pieken van 13 contrac$\operatorname{ten}^{64}$. Omdat deze cijfers weinig verhelderend zijn hebben wij de contracten per decennium gegroepeerd. Dit geeft volgend beeld:

$\begin{array}{rrcr}\text { Decennium } & \text { Wede } & \text { Mede } & \text { Tota; } \\ \text { ante } 1401 & 1 & - & 1 \\ 1401-1410 & 9 & 2 & 11 \\ 1411-1420 & 5 & - & 5 \\ 1421-1430 & 6 & 4 & 10 \\ 1431-1440 & 14 & 7 & 21 \\ 1441-1450 & 52 & 9 & 61 \\ 1451-1460 & 62 & 19 & 81 \\ 1461-1470 & 32 & 22 & 54 \\ 1471-1480 & 25 & 22 & 47 \\ & 206 & 85 & 291\end{array}$

Uit deze optelling kan blijken dat na een zeer bescheiden begin een toename van het totaal aantal contracten kan worden vastgesteld tijdens de dertiger jaren. $\mathrm{Na}$ 1440 worden hoge cijfers geboekt met een hoogtepunt in de vijftiger jaren. Daarna grijpt een langzame teruggang plaats. Van de 291 contracten werden er 243 (83\%) na 1440 afgesloten. De sterke toename van de wedecontracten gebeurt 10 jaar vroeger dan bij de medecontracten. Na 1460 vallen de wedecontracten sterk terug terwijl de mede op het bereikte niveau blijft. De algemene terugloop van het aantal contracten is dan ook uitsluitend aan de daling van de wedecontracten te wijten. In tabellen III en V werd dit cijfermateriaal grondiger ontleed.

De Rijnlandse wede onderging een sterke stimulans na 1440 maar kende reeds 10 jaar later een langzame achteruitgang. De 'Franse' wedecontracten komen alleen in 1451-1460 in noemenswaardige hoeveelheden voor en beïnvloeden dan sterk het hoge totaalcijfer. Ook de Haspengouwse wede bleek in voornoemd decennium bijzonder in trek. Men zou kunnen stellen dat Antwerpen hoofdzakelijk Rijnlandse wede heeft afgenomen maar in 1451-1460 ook op de twee andere teelt-

63. Behalve enkele lacunes in de eerste twee registers over de periode 1400-1408.

64. 11 wede, 2 mede in $1442 ; 10$ wede, 3 mede in 1459. 
TABEL III. WEDECONTRACTEN AFGESLOTEN VOOR SCHEPENEN VAN ANTWERPEN VERDELING VAN DE VERKOOPCONTRACTEN PER DECENNIUM

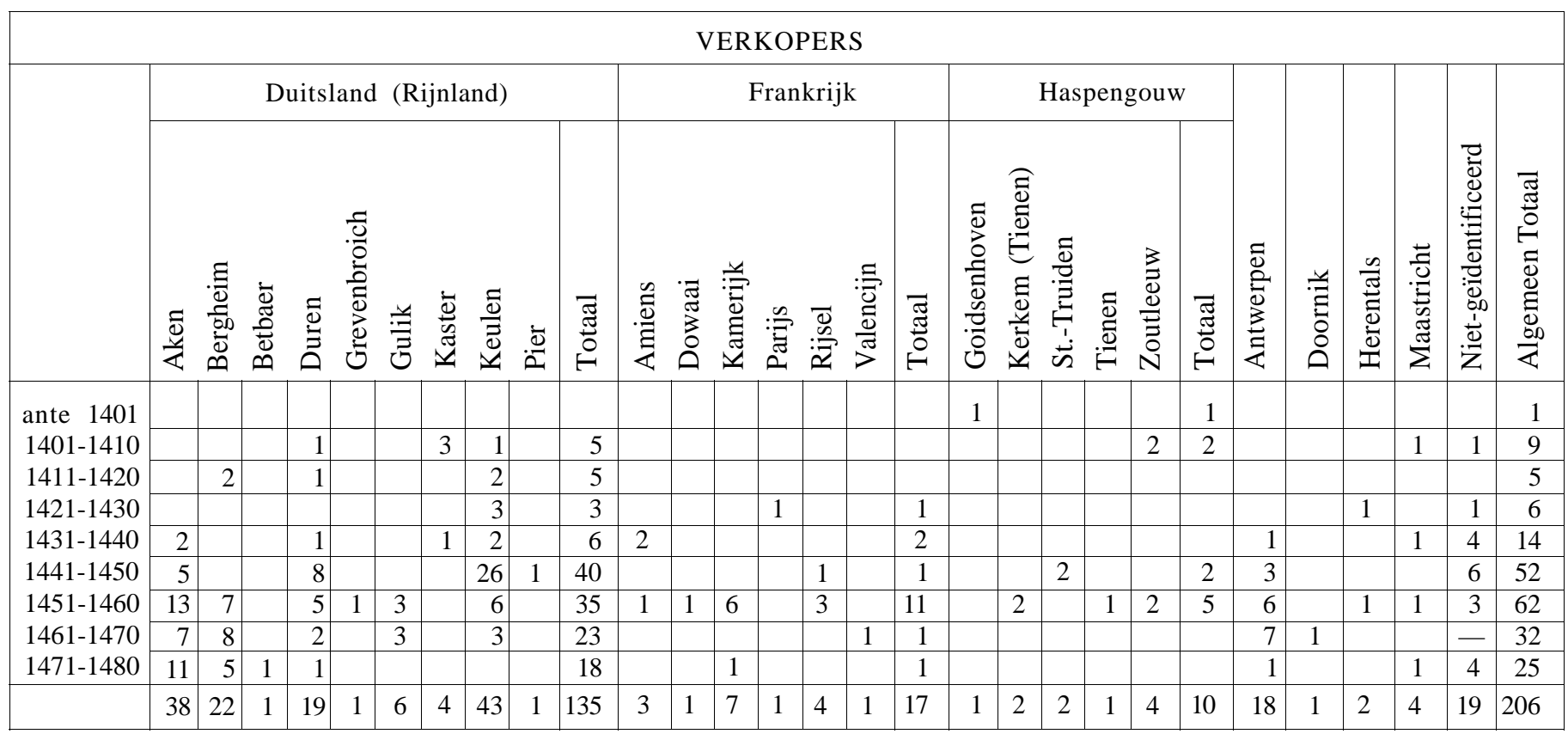


TABEL V. MEDECONTRACTEN AFGESLOTEN VOOR SCHEPENEN VAN ANTWERPEN. VERDELING VAN DE VERKOOPCONTRACTEN PER DECENNIUM

\begin{tabular}{|c|c|c|c|c|c|c|c|c|c|c|c|c|c|c|c|c|c|c|c|c|c|c|c|c|c|c|}
\hline & \multicolumn{8}{|c|}{ Brabant } & \multicolumn{3}{|c|}{ Vlaanderen } & \multicolumn{11}{|c|}{ Zeeland } & \multirow[b]{2}{*}{ 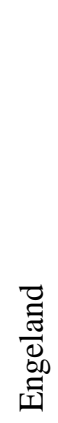 } & \multirow[b]{2}{*}{ 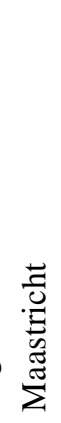 } & \multirow[b]{2}{*}{$\begin{array}{l}\frac{\partial}{0} \\
\frac{v}{8} \\
\text { है }\end{array}$} & \multirow[b]{2}{*}{ 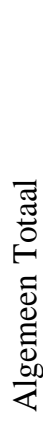 } \\
\hline & 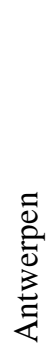 & 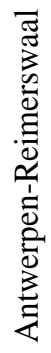 & 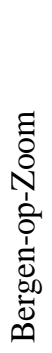 & 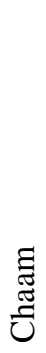 & $\frac{\tilde{D}}{\frac{D}{d}}$ & $\stackrel{\circ}{=}$ & 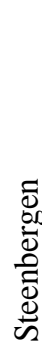 & 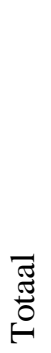 & $\stackrel{\tilde{\omega}}{\Xi}$ & 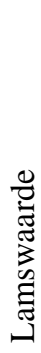 & & $\begin{array}{l}\stackrel{\Xi}{\infty} \\
\stackrel{\Xi}{\Xi} \\
\stackrel{\mathbb{N}}{0}\end{array}$ & 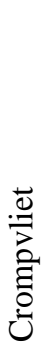 & 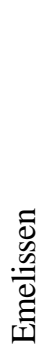 & $\begin{array}{l}\mathscr{\mho} \\
\mho \\
\mho\end{array}$ & 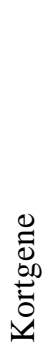 & 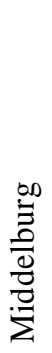 & 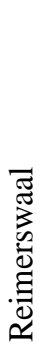 & 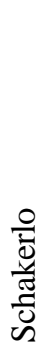 & $\frac{\overline{0}}{\stackrel{E}{O}}$ & $\begin{array}{l}\stackrel{\mathbb{N}}{N} \\
\frac{\mathbb{N}}{\mathbb{N}}\end{array}$ & 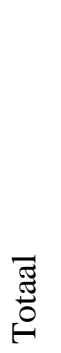 & & & & \\
\hline \multirow{9}{*}{$\begin{array}{l}1401-1410 \\
1411-1420 \\
1421-1430 \\
1431-1440 \\
1441-1450 \\
1451-1460 \\
1461-1470 \\
1471-1480\end{array}$} & 1 & & & & & & & 1 & & & & & & & & & 1 & & & & & 1 & & & & 2 \\
\hline & & & & & & & & & & & & & & & & & & & & & & & & & & - \\
\hline & 1 & & & & & 2 & & 3 & & & & 1 & & & & & & & & & & 1 & & & & 4 \\
\hline & 1 & & & & & 5 & & 6 & & & & & & & & & & & & & & & & & 1 & 7 \\
\hline & 2 & & 4 & & & & & 6 & & 1 & 1 & & & & & & & & & 1 & & 1 & & 1 & & 9 \\
\hline & 12 & 1 & 3 & & & 1 & & 17 & & & & & & & & & & & & 1 & & 1 & & & 1 & 19 \\
\hline & 7 & & 9 & & 1 & & 1 & 18 & 1 & & 1 & & 1 & & & & & & & & & 1 & 1 & & 1 & 22 \\
\hline & 4 & & 6 & 1 & & & & 11 & & & & & & 1 & 2 & 1 & & 3 & 1 & & 1 & 9 & & 1 & 1 & 22 \\
\hline & 28 & 1 & 22 & 1 & 1 & 8 & 1 & 62 & 1 & 1 & 2 & 1 & 1 & 1 & 2 & 1 & 1 & 3 & 1 & 2 & 1 & 14 & 1 & 2 & 4 & 85 \\
\hline
\end{tabular}


gebieden een beroep heeft gedaan. Was dit een periode van grote vraag naar wede? Om dit probleem te beantwoorden dient onderzocht of in die jaren veel ongeverfd laken op de Antwerpse markt werd ingevoerd. De vijftiger jaren van de vijftiende eeuw zijn alleszins gunstig geweest voor de Antwerpse lakenbereiding. Rond die tijd schijnt deze nijverheid definitief op gang te zijn gekomen. Volgens W. Brulez staat de opgang wellicht in verband met de achteruitgang van de Engelse lakenuitvoer naar de Baltische zee en de groei van de export naar de Nederlanden in de vijftiende eeuw; naar de Oostzee werd immers vooral laken in Engeland geverfd uitgevoerd, naar de Nederlanden ongeverfd laken ${ }^{65}$. Reeds in het begin van de veertiger jaren had men de crisis van 1437-1438 overwonnen ${ }^{66}$. De betrekkingen met Engeland, die na het Anglo-Bourgondisch conflict op een laag pitje stonden, verbeterden zienderogen. In 1446 werd een bestand met dit koninkrijk afgesloten. Filips de Goede verleende de Engelse koopman belangrijke privileges die door de stad werden bevestigd $^{67}$. Naast enkele ups and downs bracht de oorlog die in het begin van de vijftiger jaren in Vlaanderen woedde de Antwerpse lakenbereiding nieuwe voordelen.

De Engelse handel met Antwerpen nam nu sterk toe ${ }^{68}$. Men ging meer wede uit Haspengouw en vooral uit Noord-Frankrijk betrekken. Voor Picardië en Amiens was dit een goede oplossing. De wedehandelaars van Amiens zagen immers hun handel met Engeland wegkwijnen en grepen de gelegenheid aan om op de Brabantse jaarmarkten nieuwe contacten te leggen ${ }^{69}$. Deze voorspoedige periode werd bruusk beëindigd door het hertogelijk verbod op de Engelse lakeninvoer van 26 oktober $1464^{70}$. De hieropvolgende verplaatsing van de Engelse lakenstapel naar Utrecht was voor de Scheldestad een zware slag. De aankoop van wede daalde nu gevoelig. Van 1460 tot 1464 werden nog 31 contracten inzake wedeaankoop afgesloten. In de even lange periode van 1465 tot 1469 werden slechts 5 contracten opgemaakt. De politieke ontwikkeling van de zeventiger jaren met grote moeilijkheden tussen Karel de Stoute en Lodewijk XI van Frankrijk zouden een herstel van de Noord-Franse wedeïmport verhinderen ${ }^{71}$. Daarna zou de Toulouser pastel ook de Antwerpse markt overstromen.

De import van meekrap gebeurde uit Bourgondische landen zodat buitenlandse faktoren niet rechtstreeks deze cijfers hebben beïnvloed. De schommelingen zijn

65. W. Brulez, 'Engels laken in Vlaanderen in de 14e en 15e eeuw', Handelingen van het Genootschap 'Société d'Emulation' te Brugge, CVIII (1971) 21-22, noot 56.

66. Hierover Van der Wee, The Growth of the Antwerp Market, II, 45-49.

67. F. Prims, Geschiedenis van Antwerpen, VI (Antwerpen, 1936) 1, 125.

68. Ibidem (1937) 2, 159 .

69. Thielemans, Bourgogne et Angleterre, 235.

70. Prims, Geschiedenis van Antwerpen, VI, 2, 163.

71. Reeds in 1470 confisceerden Karel de Stoute en Lodewijk XI wederkerig de goederen van hun kooplieden. Coornaert, Les Français, 80. 


\section{G. ASAERT}

hier dan ook minder opzienbarend. Onrechtstreeks ligt natuurlijk ook hier de bloei van de lakennijverheid aan de basis. Slechts na 1470 werd de mede, tot dan hoofdzakelijk uit Brabantse gebieden betrokken, voor een belangrijk deel met mede van Zeeuwse herkomst aangevuld.

Als besluit kan worden vooropgezet dat de Antwerpse markt van de vijftiende eeuw een handel in kleurstoffen heeft gekend waarvan de sporen dank zij het schepenenprotocol tot ons zijn gekomen. Twee kleurstoffen kwamen aan bod, mede-meekrap en de meer belangrijke wede.

De wedeïnvoer vertoont interregionale aspecten. Vooral Rijnlandse wedehandelaars kwamen hun produkten te Antwerpen verkopen, subsidiair ook mensen uit het Franse noorden en uit Haspengouw, deze laatsten slechts in tijden van grote vraag naar blauwe kleurstof. De medeïnvoer heeft meer regionale karaktertrekken en kwam uit de omgeving van de Scheldestad, tijdens de zeventiger jaren meer en meer uit het belangrijkste Europese teeltgebied Zeeland.

Van deze kleurstoffen werd wede ter plaatse verbruikt, ten dele ook naar Bergenop-Zoom en de kleinere draperiesteden van de Kempen getransiteerd. Meekrap werd niet door de Antwerpse ververs verbruikt, althans blijkt dit niet uit de geregistreerde partijen. Wel was er een grote export van mede naar Engeland waaraan Antwerpse vaartuigen hun medewerking hebben verleend. Deze export ging echter vermoedelijk slechts voor een deel over de Antwerpse markt. Tenslotte is het opvallend dat wede- en meekraphandel twee duidelijk van elkaar gescheiden sectoren zijn. Het is uitzonderlijk dat een koper van wede ook meekrap kocht en omgekeerd.

De hier gepubliceerde resultaten, aan de hand van Antwerpse schepenregisters verkregen, kunnen, hoe onvolkomen zij ook mogen zijn, toch enig inzicht verschaffen in een tak van de oude textielindustrie zoals die zich op de Antwerpse markt van de vijftiende eeuw heeft ontwikkeld. Zij kunnen aantonen dat een in hoofdzaak kwalitatieve bron als het schepenenprotocol, mits voorzichtig gebruikt, toch kwantitatieve bruikbaarheid kan bieden. En precies aan kwantitatieve gegevens heeft de laat-middeleeuwse economische geschiedenis een groot gebrek.

TABEL IV. NAMENLIJST VAN WEDEVERKOPERS VERSCHENEN VOOR DE ANTWERPSE SCHEPENBANK (1394-1480)

Aken

H. Gartswilre, koopman

J. Gartswilre

J. der Guelen

P. van Kelmis al. Gartswilre
1446-1473 (1)

1465

$1461-1463$

$1460-1478$

\section{Amiens}

Math. de Jouen, koopman 1438

Thomaes de Jouen,koopman 1438

J. van Mornillet, koopman

Mottijn, koopman

(1.) De jaartallen zijn de uiterste data van vermelding in de schepenregisters. 


\section{Antwerpen}

Aerd van Corpt, wolwever 1441

1446

W. Mengiaert

1439

Jac. van der Heyden

1462-1469

Wr. Michiels, koopman

1458

Joes Knuys

1442-1443

J. van de Putte, wisselaar

1454-1460

J. van den Lare

J. van Rode

1452

Rogier van Lippeloe, koopman

1454-1473

\section{Bergheim}

Kerstiaen van Haesten, koopman

1456-1476

J. de Monic

1411-1418

P. van Haesten, koopman, vader van Kerstiaen

1456-1465

\section{Betbaer}

Hm. Hengxt

1475

P. Kerstken

1475

\section{Doornik}

Johan Verseloos, koopman

1464

Dowaai

Jacques de Hordayng al. Villette, koopman

\section{Düren}

H. Gartswilre, koopman ${ }^{2}$

H. Rootkanne, koopman

1435-1450

Math. Haer, koopman

W. Hecht

Schijn van der Hugen, koopman

Weerneer Munsterman

1476

J. Rootkanne, koopman, broeder van $\mathrm{H}$.,

Goidsenhoven

J. van Haecht

1394

Grevenbroich

Ml. van Glabbach, koopman

\section{Gulik}

Aern. van Grevenbroeck, wedekoopman

\section{Herentals}

Gijsbrecht van Berchem 1423

J. van Boekele

(2.) $\mathrm{Na} 1444$ vermeld als koopman van Aken (zie hoger p. 398).

(3.) Na 1451 vermeld als koopman van Düren (zie hoger). 


\section{G.ASAERT}

\section{Kamerijk}

Jeronimus Bolengier, koopman

1458-1460

J. Carlier, de kleine, koopman

1458

Amouri Carlier, koopman

1455-1458

Colaert de Hennijn, koopman

J. de Vryese, boogmaker en koopman

\section{Kaster}

H. den Cremer

Kerkem (Tienen)

W. de Hane

\section{Keulen}

Cl. Bernaerts, koopman

Adolf van de Bosch

1438-1449

Engbrecht van Lich

1436-1458

Coenraet van Casterle

H. van Lich, f. Engbrecht

1458

J. van Doren

1461

H. van Metorn, koopman

1405

J. onder Drievoes, koopman

J. van Ouderdrueels

1442

Jac. van Goch

1443

P. van Haesten ${ }^{5}$

1422

Adr. van Reimerswael

1447

J. Knechtken

1451-1452

Pauwels Rode

1451-1452

Zweeder van Thoor

1423-1443

Cynaert Visser

\section{Maastricht}

Gheert Breydels, waard

W. van de Kerchove

Mechelen

J. de Smit, voerman

Parijs

Remont Mart, koopman 1426

Pier

J. Roitcanne

1448

Rijsel

J. Drietssen, koopman 1455

Johan le Duutsche, koopman

1456

J. Donche, koopman

1455

J. Gantoys, koopman

Sint-Truiden

Kerstiaen Clocken, koopman 1450

Valencijn

Symoen Leffaut, koopman

(4.) In 1422 vermeld als burger van Keulen (zie verder).

(5.) Na 1452 vermeld als koopman van Bergheim (zie hoger p. 399). 
HANDEL IN KLEURSTOFFEN OP DE ANTWERPSE MARKT

\section{Zoutleeuw}

Reynere Bollen

Goesem van den Gehuchte

$1451-1453$

H. van Lijkenrode

1406

W. van Ghelmen

1406

P. van Ransbeke

1451

1451

TABEL VI. NAMENLIJST VAN MEEKRAPVERKOPERS

VERSCHENEN VOOR DE ANTWERPSE SCHEPENBANK (1405-1480)

\section{Antwerpen}

Adr., f. J. Gielissone

$1431^{l}$

Erven Corn. Michielssone, kordewagenkruider

1469

Katl. Daens, wed. Math. van der Schueren

Berwout van der Heyden, droogscheerder

J. Zymoenssone, twijnverver 1468

P. van Karrenbroeck, stadssecretaris

Andr. Knobbaert, meersenier

Laur. Michielssone, smoutslager

1468

\section{Bergen-op-Zoom}

Rombout Aelbrechts

Corn. Henricxsone

Joos van der Couveringen

$\mathrm{Hm}$. Haeck

1461

J. Coelgheenensoen

1446-1464

1474

J., f. Jac. Janssone

1461

Joes Janssone

1461-68

H. Oele, schipper

1468-1471

Peter Pot, koopman

1425

Thomas van Riethoven

1456

W. van Riethoven

1456

Aerd Schoenhout, koopman 1443

Aern. Tollinc

1405

Math. de Waeyere

1472

Wisse Heinricxssone, zouthandelaar

$1455-1473$

H. Zebrechts

1456

Kerstoffel Corneliszone
Jac. Loey

Cl. Norijs, bontwerker

Jac. Norijs

P. Coelgheenensoen

Anthonis Pycolet

Wr., f. Huyge Bonefaes
1459

1471

1461-1462

$1449-1469$

1479

1453

Biezelinge

P. Willemssone

Chaam

J. Peters

Crompvliet

J. Adriaenssone

Emelissen

Giel. Claussone

(1.) De jaartallen duiden op de periode van vermelding in de schepenregisters. 


\section{G.ASAERT}

Engeland

Eduwaerd Elsmeer

1470

Goes

Corn. Huygensone

1476-1479

Halsteren

H. Heinricxsone

1466

Hulst

Corn. Merten Ghijsbrechtszone

Hulst/Lamswaarde

W. Mijs

1442

Kortgene

W. Huygesone

1478

Lillo

J. de Beste al. Pieterssone

1421-1432

W. Aertssone

1457

Laur., f. J. Neeten

1421-1435

Zeger IJsensone

1431

Maastricht

Gheert Breydels, waard

1471

H. Knijcf

1445

Middelburg

P. Huygsone

1405

Reimerswaal

Corn. Oertssone 1479

J. Willemssone, landmeter

1455

Symoen Symoenssone

$1473-$

Schakerlo

Corn. Lam, f. Giel

1472

Steenbergen

Jac. Boydens

1461

Tholen

Corn. van Dalem

1459

Godt. Hermanszone

Zierikzee

Corn. Lambrechtssone 